\title{
Curcumin inhibits the development of non-small cell lung cancer by inhibiting autophagy and apoptosis
}

\author{
AILI WANG, JINXIANG WANG, SHUMING ZHANG, HONGXIA ZHANG, ZHENYANG XU and XIAOHUI LI \\ Department of Respiratory and Critical Care Medicine, Beijing Luhe Hospital, \\ Capital Medical University, Beijing 101100, P.R. China
}

Received September 6, 2016; Accepted May 15, 2017

DOI: $10.3892 /$ etm.2017.5172

\begin{abstract}
Among patients with primary lung cancer, 75-80\% present with non-small cell lung cancer (NSCLC). However, there is a lack of studies into the potential preventive effects of curcumin against the activation of autophagy in NSCLC. Therefore, the present study primarily focused on the protective role of curcumin in NSCLC. It was demonstrated that curcumin decreased the viability of the human lung cancer cells lines, A549 and H1299, in a time-and dose-dependent manner $(\mathrm{P}<0.05)$. Treatment with curcumin also suppressed the colony formation capacities of A549 and H1299 cells. Following incubation with $10 \mu \mathrm{M}$ curcumin for $48 \mathrm{~h}$, cell apoptosis was significantly increased by 2.35 - and 3.02 -fold in A549 and H1299 cells, respectively, when compared with controls $(\mathrm{P}<0.01)$. Furthermore, curcumin treatment markedly increased the number and volume of autophagosomes in A549 and H1299 cells when compared with controls. Treatment with $10 \mu \mathrm{M}$ curcumin for $48 \mathrm{~h}$ also significantly reduced the phosphorylation levels of mechanistic target of rapamycin (mTOR), ribosomal protein S6, phosphoinositide 3-kinase and AKT (protein kinase B) in A549 and H1299 cells $(\mathrm{P}<0.05)$. These data indicated that curcumin enhanced autophagy and apoptosis in NSCLC cells by acting as an mTOR complex1/2 inhibitor.
\end{abstract}

\section{Introduction}

As the most common cause of cancer-related mortality, lung cancer is divided into small cell lung cancer (SCLC) and non-small cell lung cancer (NSCLC) (1). It is estimated that $75-80 \%$ of patients with primary lung cancer present with NSCLC $(2,3)$. At present, surgery is the most effective treatment method for NSCLC. However, the postoperative

Correspondence to: Dr Aili Wang, Department of Respiratory and Critical Care Medicine, Beijing Luhe Hospital, Capital Medical University, 82 Xinhua Nanlu, Beijing 101100, P.R. China

E-mail:m18254831270_1@163.com

Key words: curcumin, autophagy, apoptosis, non-small cell lung cancer prognosis remains poor and the 5-year survival rate for NSCLC is reported to be $<20 \%$ (4). Thus, it is necessary to develop novel prevention and treatment strategies that effectively manage NSCLC.

More recently, autophagy has become established as an important cellular process involved in the development of NSCLC $(5,6)$. Autophagy primarily refers to degradation of cytoplasmic content, superfluous or damaged organelles and engulfment of pathogens (7-9). The mechanism by which autophagy regulates cancer is complex and principally depends on the tumor type and stage (10). Under homeostatic conditions, autophagy generally suppresses the progression of cancer, and abnormal activation of autophagy may lead to malignancy, as observed for NSCLC (11-13). Therefore, insight into the regulation of homeostasis may aid to identify effective therapeutic methods that prevent the progression of NSCLC.

Curcumin is a natural polyphenol that is extracted from the spice turmeric, and is characterized by anti-inflammatory, anti-oxidative, anti-carcinogenic and immuno-regulatory activities (14). In mice, it has been observed that treatment with curcumin decreased Helicobacter pylori infection and suppressed infection-induced gastric damage (15). In a clinical trial, an average curcumin dose of $500 \mathrm{mg}$ for 7 days markedly decreased the level of serum lipid peroxide, as a biomarker of oxidative stress (16). Furthermore, an enhanced therapeutic effect against cancer has been observed when curcumin was used alone or in combination with chemotherapeutic agents $(17,18)$. However, to the best of our knowledge, no previous studies have investigated the potential protective effects of curcumin against the activation of autophagy in NSCLC. This was the focus of the present study.

The present study explored the effects of curcumin on the proliferation and migration of lung cancer cells. The findings indicated that curcumin reduced cell growth and suppressed colony formation capacity in human NSCLC cells. Furthermore, abnormal activation of autophagy was inhibited following curcumin treatment, indicating that curcumin may be a useful anticancer agent for the treatment of NSCLC.

\section{Materials and methods}

Lung cancer cell lines and cell culture. The human lung cancer cells lines, A549 and H1299 (American Type Culture Collection, Manassas, VA, USA) were cultured in RPMI-1640 
medium and Dulbecco's modified Eagle's medium (DMEM) both supplemented with 10\% fetal bovine serum (FBS) (all from Gibco; Thermo Fisher Scientific, Inc., Waltham, MA, USA), respectively. The cells were incubated under humidified conditions at $37^{\circ} \mathrm{C}$ and $5 \% \mathrm{CO}_{2}$.

Cell proliferation assay. Curcumin was purchased from Cayman Chemical Company (Ann Arbor, MI, USA). To determine the effects of curcumin on cell proliferation, A549 and H1299 cells were seeded into 96-well tissue culture plates at a density of $5 \times 10^{3}$ cells/well. Cells were administered with medium only (containing $0.01 \%$ dimethyl sulfoxide as a negative control) or incubated with $0.5,1,5,10$ and $20 \mu \mathrm{M}$ curcumin. Following incubation for 24,48 and $72 \mathrm{~h}$ at $37^{\circ} \mathrm{C}$, cell viability was determined with an 3-(4,5-dimethylthiazol-2-yl)-2,5-di-phenyltetrazolium bromide (MTT) assay (Sigma-Aldrich; Merck KGaA; Darmstadt, Germany). Following treatment, the cells were cultured in fresh media containing $0.5 \mathrm{mg} / \mathrm{ml} \mathrm{MTT}$ for $4 \mathrm{~h}$. Dimethyl sulfoxide (DMSO; Sigma-Aldrich; Merck KGaA) was then added to the wells to dissolve the formazan products and the absorbance was measured spectrophotometrically at a wavelength of $550 \mathrm{~nm}$. Three replicates were performed and analyzed.

Cell apoptosis assay. Following $10 \mu \mathrm{M}$ curcumin or DMSO control treatment for $48 \mathrm{~h}$, the cells were washed three times with cold phosphate-buffered saline (PBS). An Annexin V-fluorescein isothiocyanate (FITC)-propidium iodide (PI) Apoptosis kit (Invitrogen; Thermo Fisher Scientific, Inc.) was used to measure cell apoptosis. Briefly, cells were washed three times with $1 \mathrm{X}$ PBS and suspended at a density of $2-3 \times 10^{6}$ cells $/ \mathrm{ml}$ in $1 \mathrm{X}$ Annexin V-binding buffer $(10 \mathrm{mM}$ HEPES/NaOH, pH 7.4, $140 \mathrm{mM} \mathrm{NaCl}, 2.5 \mathrm{mM} \mathrm{CaCl}$ ). Annexin V-FITC and PI buffer was administered to the cells, which were then incubated for $15 \mathrm{~min}$ at room temperature in the dark. Cells lacking treatment with curcumin were used as an internal control. Following incubation, the cells were filtered with a 200-mesh filter screen and analyzed with a FACScan flow cytometer (BD Biosciences, San Jose, CA, USA) within $1 \mathrm{~h}$ of staining. Cell apoptosis was analyzed using BD CellQuest Pro software (BD Biosciences). A total of 10,000 cells were evaluated in each sample.

Western blotting. Following $10 \mu \mathrm{M}$ curcumin or DMSO control treatment for $48 \mathrm{~h}$, cell protein was extracted using radioimmunoprecipitation assay buffer (Solarbio Science \& Technology Co., Ltd., Beijing, China) and was collected after centrifugation at $10,000 \mathrm{x}$ g at $4^{\circ} \mathrm{C}$ for $20 \mathrm{~min}$. A bicinchoninic protein assay kit (Pierce; Thermo Fisher Scientific, Inc.) was used to determine the protein concentration. A total of $15 \mu \mathrm{g}$ protein was loaded per lane and separated by $10 \%$ SDS-PAGE and transferred to polyvinylidene difluoride membranes (EMD Millipore, Billerica, MA, USA). The membranes were blocked with $8 \%$ nonfat dry milk at $4^{\circ} \mathrm{C}$ overnight. Following three washes with PBS with Tween-20 (5 min/wash), the membranes were incubated with primary antibodies at $4^{\circ} \mathrm{C}$ overnight. The blots were then incubated with horseradish peroxidase (HRP)-conjugated anti-immunoglobulin G (all 1:5,000; Zhongshan Gold Bridge Biological Technology Co., Beijing, China) for $2 \mathrm{~h}$ at room temperature and then washed. Protien detection was performed with enhanced chemiluminescent substrate (EMD Millipore). Primary antibodies against microtubule-associated protein 1 light chain 3 II/I (LC3II/I; L8918, 1:1,000, Sigma-Aldrich; Merck KGaA), beclin-1 (cat no. $3495 ; 1: 1,000)$, mechanistic target of rapamycin (mTOR; cat no. 2983; 1:1,000), phosphorylated (p)-mTOR (cat no. 5536; 1:1,000), ribosomal protein S6 (cat no. 2217; 1:1,000), p-S6 (cat no. 4858; 1:1,000), phosphoinositide 3-kinase (PI3K; cat no. 4249; 1:1,000), p-PI3K (cat no. 4228; 1:1,000), AKT (protein kinase B; cat no. 9840; 1:1,000), p-AKT (cat no. 8200; 1:1,000) and $\beta$-actin (cat no. 4970; 1:1,000) (all from Cell Signaling Technology, Inc., Boston, MA, USA). $\beta$-actin was used as an internal control. ImageJ software (National Institutes of Health, Bethesda, MD, USA) was used for density analysis.

Colony formation assay. Cells were suspended in $0.3 \%$ agar (Sigma-Aldrich; Merck KGaA) in RPMI-1640 or DMEM with or without $10 \mu \mathrm{M}$ curcumin treatment for $48 \mathrm{~h}$ and plated at a density of $1 \times 10^{5}$ cells/dish into a $10-\mathrm{cm}$ dish, which was preloaded with a thin layer of $1.0 \%$ agar. Cells were maintained in RPMI-1640 or DMEM supplemented with 10\% FBS during the assay and monitored for colony formation. After culturing for 7 days, the colony formation was observed. The clones were stained with trypan blue (Sigma-Aldrich; Merck $\mathrm{KGaA}$ ) at room temperature for $15 \mathrm{~min}$ to evaluate colony formation.

Electron microscopy. Following $10 \mu \mathrm{M}$ curcumin or DMSO control treatment for $48 \mathrm{~h}$, cells were centrifuged at $800 \mathrm{x} \mathrm{g}$ for $10 \mathrm{~min}$ at room temperature and the cell pellets were fixed at room temperature in $2.3 \%$ glutaraldehyde for $1 \mathrm{~h}$, postfixed in $2 \%$ osmium tetroxide (O5500; Sigma-Aldrich; Merck KGaA) at $4^{\circ} \mathrm{C}$ for $30 \mathrm{~min}$ and $0.5 \%$ uranyl acetate (EMD Millipore) at room temperature for $15 \mathrm{~min}$, dehydrated and embedded in Spurr epoxy resin (Shanghai Huake Co., Ltd., Shanghai, China) at $4^{\circ} \mathrm{C}$ overnight. Ultrathin sections (90 nm) were cut and double-stained with $3 \%$ uranyl acetate and lead citrate (Solarbio, Science \& Technology Co., Ltd.) at room temperature for $20 \mathrm{~min}$, and viewed with a Philips CM10 transmission electron microscope (Phillips Electronics, Amsterdam, The Netherlands).

Statistical analysis. Data are presented as the mean \pm standard deviation for the indicated number of separate experiments. Three independent experiments were performed for each study. Data were statistically evaluated with an unpaired Student's t-test using GraphPad Prism software (version 6.0; GraphPad Software, Inc., LaJolla, CA, USA). P<0.05 was considered to indicate a statistically significant difference.

\section{Results}

Curcumin decreases human lung cancer cell viability in a time- and dose-dependent manner. A549 and H1299 cells were treated with $0.5,1,5,10$ and $20 \mu \mathrm{M}$ curcumin for $48 \mathrm{~h}$ and cell viability was determined using an MTT assay. As depicted in Fig. 1A and B, treatment with 5, 10 and $20 \mu \mathrm{M}$ curcumin significantly suppressed cell proliferation when compared with control cells (for A549 cells: $\mathrm{P}<0.05$ for $5 \mu \mathrm{M}$ curcumin and $\mathrm{P}<0.01$ for 10 and $20 \mu \mathrm{M}$ curcumin; for 
A

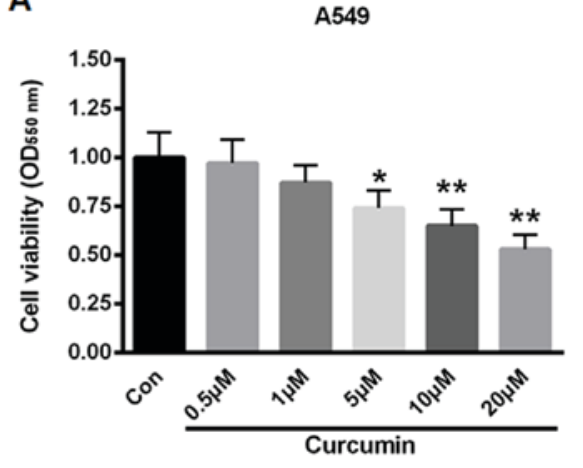

C

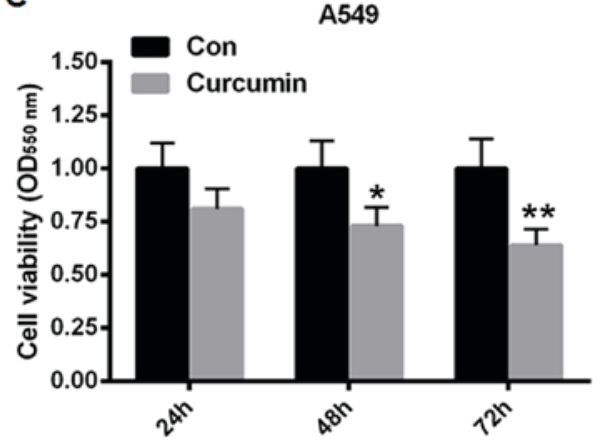

B

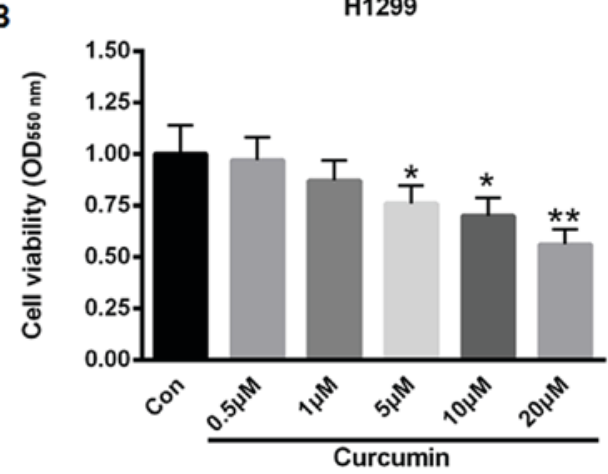

D

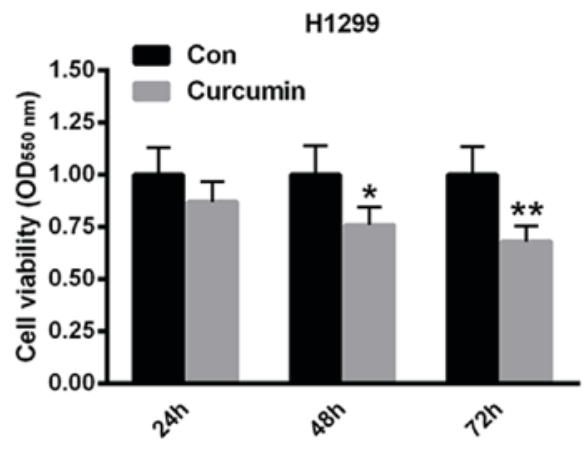

Figure 1. Curcumin decreases A549 and H1299 cell viability in a time- and dose-dependent manner. Treatment of (A) A549 and (B) H1299 cells with 0.5, 1 , 5,10 and $20 \mu \mathrm{M}$ curcumin for $48 \mathrm{~h}$ decreased cell viability. Incubation with $10 \mu \mathrm{M}$ curcumin for 24,48 and $72 \mathrm{~h}$ also reduced the viability of (C) A549 and (D) H1299 cells. "P<0.05 and ${ }^{* *} \mathrm{P}<0.01$ vs. Con. OD, optical density; Con, control.
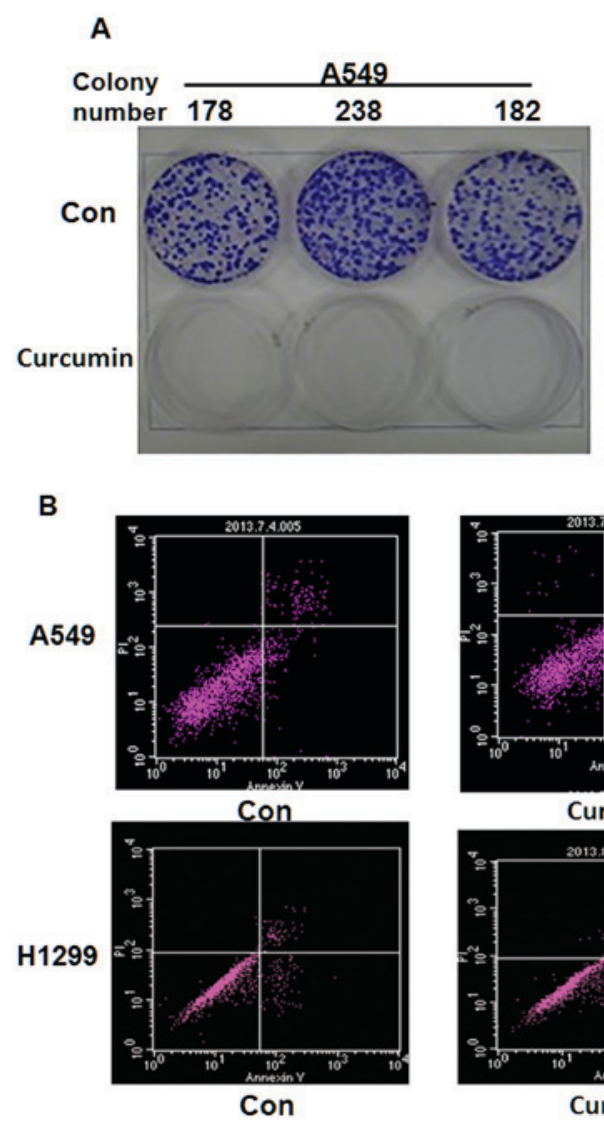

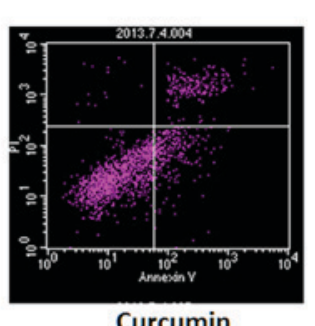

Curcumin

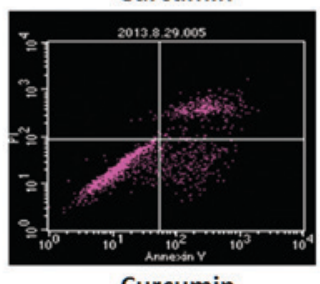

Curcumin
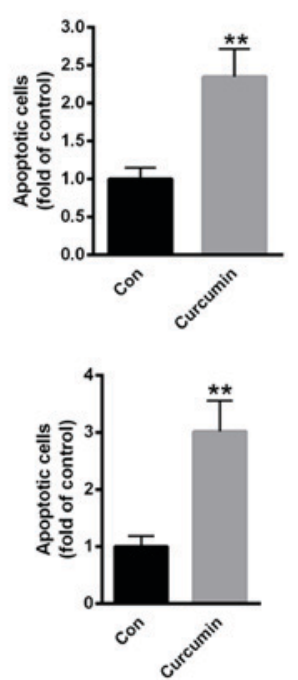

Figure 2. Curcumin inhibits colony formation and promoted cell apoptosis. (A) Curcumin treatment suppressed the colony formation capacity of both A549 and H1299 cells. (B) Incubation with $10 \mu \mathrm{M}$ curcumin for $48 \mathrm{~h}$ increased cell apoptosis in A549 and H1299 cells. " P $<0.01$ vs. Con. PI, propidium iodide; Con, control. 
A
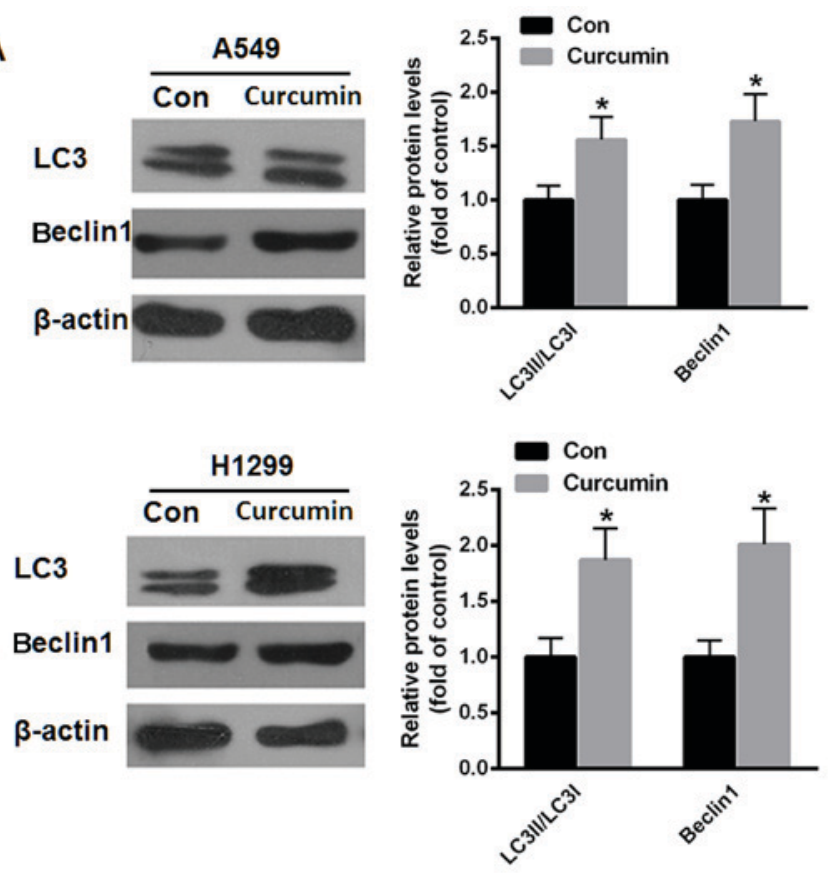

B

A549

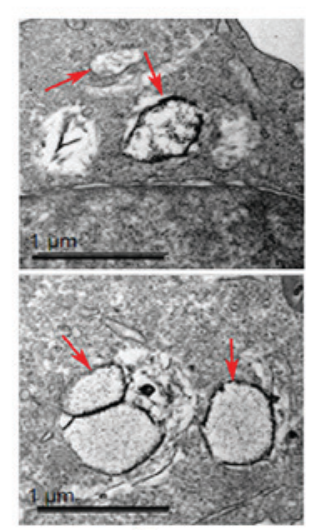

Con

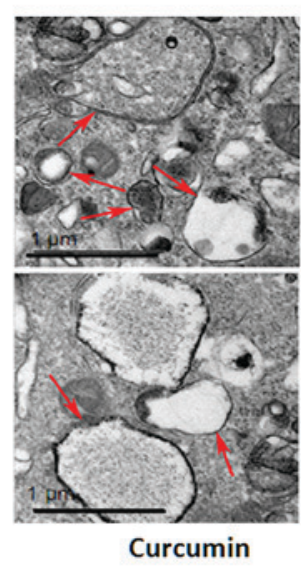

Figure 3. Curcumin enhances autophagy in human lung cancer cells. (A) Western blot analysis of the LC3-II/LC3-I ratio and protein level of beclin-1 in A549 and H1299 cells treated with $10 \mu \mathrm{M}$ curcumin for $48 \mathrm{~h}$. (B) Electronic microphotography demonstrated that curcumin markedly increased the number and volume of autophagosomes (red arrows). Scale bar length represents $1 \mu \mathrm{m}$; magnification, $\mathrm{x} 400 .{ }^{*} \mathrm{P}<0.05$ vs. Con. LC3, microtubule-associated protein 1 light chain 3 ; Con, control.

H1299 cells: $\mathrm{P}<0.05$ for 5 and $10 \mu \mathrm{M}$ curcumin and $\mathrm{P}<0.01$ for $20 \mu \mathrm{M}$ curcumin). Furthermore, when A549 and H1299 cells were incubated with $10 \mu \mathrm{M}$ curcumin for 24,48 , and $72 \mathrm{~h}$, cell proliferation was significantly reduced by 27 and $36 \%$ for A549 cells, and 24 and 32\% for H1299 cells at 48 and $72 \mathrm{~h}$, respectively (Fig. 1C and D). These data suggested that curcumin decreased the viability of A549 and H1299 cells in a time- and dose-dependent manner.

Curcumin inhibits colony formation and promotes apoptosis. A549 and H1299 cells were subsequently treated with $10 \mu \mathrm{M}$ curcumin for $48 \mathrm{~h}$ and the colony formation capacity of cells was determined. As depicted in Fig. 2A, treatment with curcumin suppressed the colony formation capacities of both A549 and H1299 cells. Cell apoptosis was also measured using flow cytometry. Following incubation with $10 \mu \mathrm{M}$ curcumin

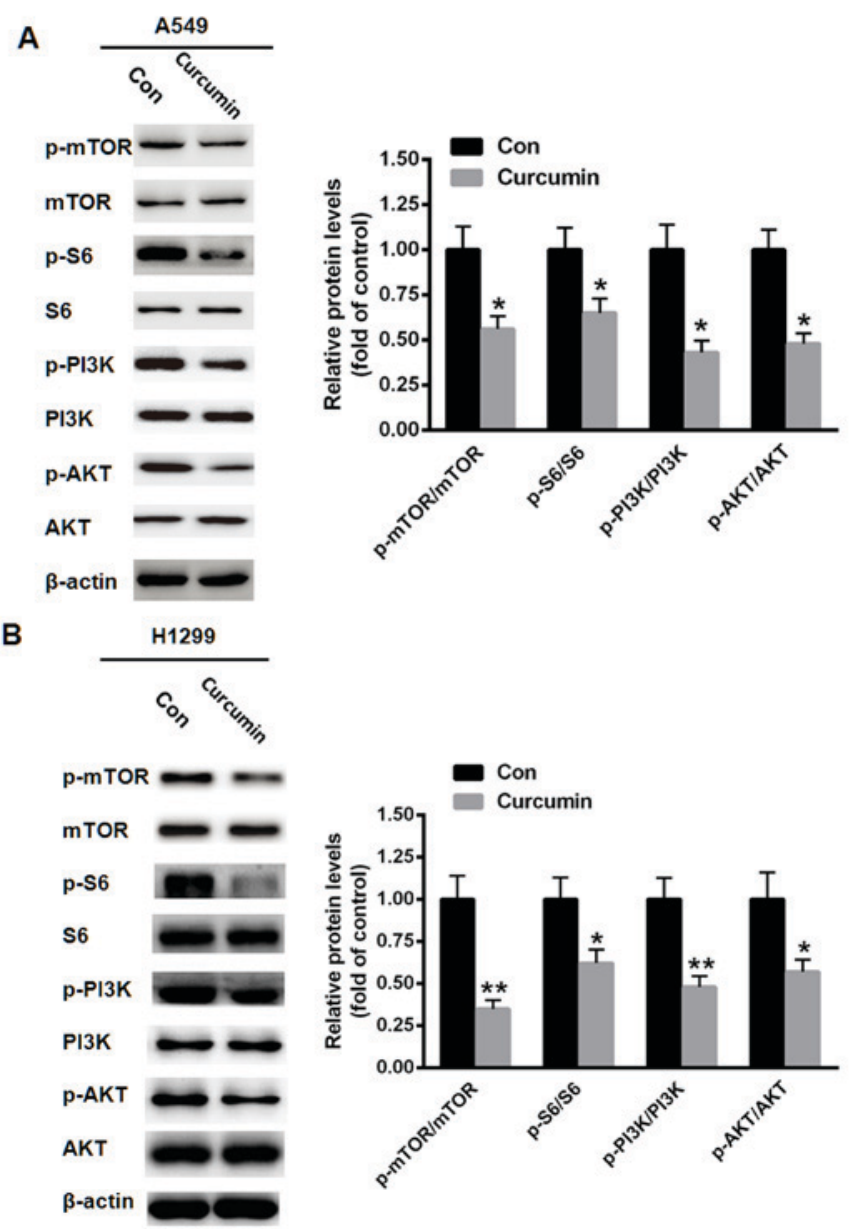

Figure 4. Curcumin suppresses PI3K/mTOR activation. Treatment with $10 \mu \mathrm{M}$ curcumin reduced the activation of $\mathrm{P} 13 \mathrm{~K} / \mathrm{mTOR}$ signaling in (A) A549 and (B) H1299 cells. ${ }^{*} \mathrm{P}<0.05$ and ${ }^{* *} \mathrm{P}<0.01$ vs. Con. PI3K, phosphoinositide 3-kinase; mTOR, mechanistic target of rapamycin; p-, phosphorylated.

for $48 \mathrm{~h}$, cell apoptosis was significantly increased by 2.35 and 3.02-fold in A549 and H1299 cells, respectively, when compared with controls ( $\mathrm{P}<0.01$; Fig. 2B).

Curcumin enhances autophagy in human lung cancer cells. It was also determined whether curcumin induced cell autophagy in lung cancer cells. Following treatment with $10 \mu \mathrm{M}$ curcumin for $48 \mathrm{~h}$, western bolt analysis demonstrated that the ratio of LC3-II to LC3-I and protein level of beclin-1 were significantly increased in A549 and H1299 cells ( $\mathrm{P}<0.05$; Fig. 3A). Electronic microphotography was also used to assess the autophagosomes in each group. As depicted in Fig. 3B, curcumin markedly increased the number and volume of autophagosomes in curcumin-treated cells when compared with controls, indicating that curcumin may induce cell autophagy in human lung cancer cells.

Curcumin suppresses PI3K/mTOR activation. It has been documented that $\mathrm{P} 13 \mathrm{~K} / \mathrm{mTOR}$ signaling serves a key inhibitory role in the autophagy of various types of human cancer (19). Therefore, the activation of P13K/mTOR signaling following curcumin treatment was evaluated. As depicted in Fig. 4, treatment with $10 \mu \mathrm{M}$ curcumin for $48 \mathrm{~h}$ markedly reduced the phosphorylation levels of mTOR, S6, PI3K and AKT in A549 
(all $\mathrm{P}<0.05)$ and $\mathrm{H} 1299(\mathrm{P}<0.05$ for $\mathrm{S} 6$ and $\mathrm{AKT}, \mathrm{P}<0.01$ for mTOR and PI3K) cells.

\section{Discussion}

Lung cancer has been reported as the most common cause of cancer-related mortality (20). Therefore, detailed studies into the oncological mechanisms of lung cancer are required for the development of improved therapeutics. The majority of lung carcinomas present as NSCLC (20). In signaling pathways related to cell growth and proliferation, the PI3K/AKT/mTOR pathway serves a key role $(21,22)$. Aberrant regulation of the $\mathrm{PI} 3 \mathrm{~K} / \mathrm{AKT} / \mathrm{mTOR}$ pathway has been identified in various types of tumor, including prostate, breast, lung and liver cancer $(22,23)$. Recent studies have investigated the potential of mTOR targeting as a molecular-targeting therapy for the treatment of human cancers $(24,25)$.

The present study focused on curcumin, as a natural polyphenol isolated from the spice turmeric (26). Previous studies have demonstrated that curcumin suppresses cytotoxicity and DNA injury by suppressing oxidative damage caused by reactive oxygen species $(27,28)$. The current study observed that curcumin decreased the viability of human lung cancer cells in an apparent dose- and time-dependent manner. Furthermore, cell apoptosis was increased and colony formation capacity was inhibited by curcumin treatment, as determined by annexin V-PI staining and evaluation of colony numbers, respectively. These results indicated that curcumin reduced the viability of lung cancer cells by promoting cell apoptosis and reducing colony formation capacity.

Autophagy is a complex process and is under fine regulation, which depends upon the physiological and pathological conditions of the cellular environment (29). As such, autophagy has become established as a potential anti-cancer therapeutic (24). The process of autophagy may stimulate the degradation of cytoplasmic content in the lysosomal compartment of cells at a cellular level (30). The maintenance of autophagy at a steady level is a possible therapeutic target for anti-cancer therapy. In the process of autophagy, the conversion of LC3-I into LC3-II form is regarded as a hallmark of autophagy, and prompts the formation of the autophagosome (29). In the present study, it was observed that curcumin enhanced autophagy in lung cancer cells, potentially by acting as an mTOR complex $1 / 2$ inhibitor.

In conclusion, the present findings demonstrated novel data that curcumin suppressed mTOR/PI3K/AKT signaling, thereby inducing lung cancer cell apoptosis and autophagy. Thus, curcumin is a potential therapeutic for the treatment of human NSCLC. However, the present study lacks in vivo experiments and further clinical investigation is required.

\section{References}

1. Clark PA: Puberty: When it comes too soon guidelines for the evaluation of sexual precocity. J Ky Med Assoc 96: 440-447, 1998.

2. Lv X, Liu F, Shang Y and Chen SZ: Honokiol exhibits enhanced antitumor effects with chloroquine by inducing cell death and inhibiting autophagy in human non-small cell lung cancer cells. Oncol Rep 34: 1289-1300, 2015.

3. Zhao R, Chen M, Jiang Z, Zhao F, Xi B, Zhang X, Fu H and Zhou K: Platycodin-D induced autophagy in non-small cell lung cancer cells via PI3K/Akt/mTOR and MAPK signaling pathways. J Cancer 6: 623-631, 2015.
4. Lu W, Zhang H, Niu Y, Wu Y, Sun W, Li H, Kong J, Ding K, Shen HM, Wu H, et al: Long non-coding RNA linc00673 regulated non-small cell lung cancer proliferation, migration, invasion and epithelial mesenchymal transition by sponging miR-150-5p. Mol Cancer 16: 118, 2017.

5. Choi JY, Hong WG, Cho JH, Kim EM, Kim J, Jung CH, Hwang SG, Um HD and Park JK: Podophyllotoxin acetate triggers anticancer effects against non-small cell lung cancer cells by promoting cell death via cell cycle arrest, ER stress and autophagy. Int J Oncol 47: 1257-1265, 2015.

6. Giatromanolaki A, Kalamida D, Sivridis E, Karagounis IV, Gatter KC, Harris AL and Koukourakis MI: Increased expression of transcription factor EB (TFEB) is associated with autophagy, migratory phenotype and poor prognosis in non-small cell lung cancer. Lung Cancer 90: 98-105, 2015.

7. Hwang KE, Kim YS, Jung JW, Kwon SJ, Park DS, Cha BK, Oh SH, Yoon KH, Jeong ET and Kim HR: Inhibition of autophagy potentiates pemetrexed and simvastatin-induced apoptotic cell death in malignant mesothelioma and non-small cell lung cancer cells. Oncotarget 6: 29482-29496, 2015.

8. Izdebska M, Klimaszewska-Wiśniewska A, Hałas M, Gagat M and Grzanka A: Green tea extract induces protective autophagy in A549 non-small lung cancer cell line. Postepy Hig Med Dosw (Online) 69: 1478-1484, 2015

9. Lee JG, Shin JH, Shim HS, Lee CY, Kim DJ, Kim YS and Chung KY: Autophagy contributes to the chemo-resistance of non-small cell lung cancer in hypoxic conditions. Respir Res 16: $138,2015$.

10. Liu JT, Li WC, Gao S, Wang F, Li XQ, Yu HQ, Fan LL, Wei W, Wang $\mathrm{H}$ and Sun GP: Autophagy inhibition overcomes the antagonistic effect between gefitinib and cisplatin in epidermal growth factor receptor mutant non-small-cell lung cancer cells. Clin Lung Cancer 16: e55-e66, 2015.

11. Wei J, Ma Z, Li Y, Zhao B, Wang D, Jin Y and Jin Y: miR-143 inhibits cell proliferation by targeting autophagy-related $2 \mathrm{~B}$ in non-small cell lung cancer H1299 cells. Mol Med Rep 11: 571-576, 2015.

12. Xu JH, Yang HP, Zhou XD, Wang HJ, Gong L and Tang CL: Autophagy accompanied with bisdemethoxycurcumin-induced apoptosis in non-small cell lung cancer cells. Biomed Environ Sci 28: 105-115, 2015.

13. Zhang L, Dai F, Sheng PL, Chen ZQ, Xu QP and Guo YQ: Resveratrol analogue 3,4,4'-trihydroxy-trans-stilbene induces apoptosis and autophagy in human non-small-cell lung cancer cells in vitro. Acta Pharmacol Sin 36: 1256-1265, 2015.

14. Sankar P, Telang AG, Ramya K, Vijayakaran K, Kesavan M and Sarkar SN: Protective action of curcumin and nano-curcumin against arsenic-induced genotoxicity in rats in vivo. Mol Biol Rep 41: 7413-7422, 2014.

15. De R, Kundu P, Swarnakar S, Ramamurthy T, Chowdhury A, Nair GB and Mukhopadhyay AK: Antimicrobial activity of curcumin against Helicobacter pylori isolates from India and during infections in mice. Antimicrob Agents Chemother 53: 1592-1597, 2009

16. Soni KB and Kuttan R: Effect of oral curcumin administration on serum peroxides and cholesterol levels in human volunteers. Indian J Physiol Pharmacol 36: 273-275, 1992.

17. Betts JW, Sharili AS, La Ragione RM and Wareham DW: In vitro antibacterial activity of curcumin-polymyxin B combinations against multidrug-resistant bacteria associated with traumatic wound infections. J Nat Prod 79: 1702-1706, 2016.

18. Zhu DJ, Huang YF, Chen XW, Luo ZT, Wang GX, Liu CC, Zhang WJ and Ouyang MZ: Curcumin partly ameliorates irinotecan-induced diarrhea and synergistically promotes apoptosis in colorectal cancer through mediating oxidative stress. Oncotarget: Jul 14, 2016 (Epub ahead of print).

19. Bjelogrlić SK, Srdić T and Radulović S: Mammalian target of rapamycin is a promising target for novel therapeutic strategy against cancer. J BUON 11: 267-276, 2006.

20. Micke P, Mattsson JS, Djureinovic D, Nodin B, Jirström K, Tran L, Jönsson P, Planck M, Botling J and Brunnström H: The impact of the fourth edition of the WHO classification of lung tumours on histological classification of resected pulmonary NSCCs. J Thorac Oncol 11: 862-872, 2016.

21. Laplante M and Sabatini DM: mTOR signaling in growth control and disease. Cell 149: 274-293, 2012.

22. Efeyan A and Sabatini DM: mTOR and cancer: Many loops in one pathway. Curr Opin Cell Biol 22: 169-176, 2010.

23. Salmena L, Carracedo A and Pandolfi PP: Tenets of PTEN tumor suppression. Cell 133: 403-414, 2008. 
24. Benjamin D, Colombi M, Moroni C and Hall MN: Rapamycin passes the torch: A new generation of mTOR inhibitors. Nat Rev Drug Discov 10: 868-880, 2011.

25. Baehrecke EH: Autophagy: Dual roles in life and death? Nat Rev Mol Cell Biol 6: 505-510, 2005.

26. Shi J, Wang Y, Jia Z, Gao Y, Zhao C and Yao Y: Curcumin inhibits bladder cancer progression via regulation of $\beta$-catenin expression. Tumour Biol 39: 1010428317702548, 2017.

27. Granados-Castro LF, Rodríguez-Rangel DS, Fernández-Rojas B, León-Contreras JC, Hernández-Pando R, Medina-Campos ON, Eugenio-Pérez D, Pinzón E and Pedraza-Chaverri J: Curcumin prevents paracetamol-induced liver mitochondrial alterations. J Pharm Pharmacol 68: 245-256, 2016.
28. Trujillo J, Molina-Jijón E, Medina-Campos ON, Rodríguez-Muñoz R, Reyes JL, Loredo ML, Barrera-Oviedo D, Pinzón E, Rodríguez-Rangel DS and Pedraza-Chaverri J: Curcumin prevents cisplatin-induced decrease in the tight and adherens junctions: Relation to oxidative stress. Food Funct 7: 279-293, 2016.

29. Kabeya Y, Mizushima N, Ueno T, Yamamoto A, Kirisako T, Noda T, Kominami E, Ohsumi Y and Yoshimori T: LC3, a mammalian homologue of yeast Apg8p, is localized in autophagosome membranes after processing. EMBO J 19: 5720-5728, 2000.

30. Huang S, Shu L, Dilling MB, Easton J, Harwood FC, Ichijo H and Houghton PJ: Sustained activation of the JNK cascade and rapamycin-induced apoptosis are suppressed by p53/p21(Cip1). Mol Cell 11: 1491-1501, 2003. 